\title{
STACKELBERG LEADERSHIP WITH PRODUCT DIFFERENTIATION AND ENDOGENOUS ENTRY: SOME COMPARATIVE STATIC AND LIMITING RESULTS
}

\author{
Krešimir Žigić
}
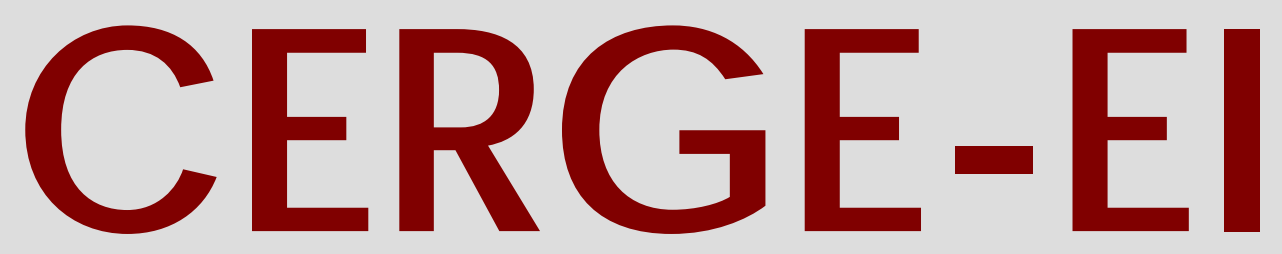

Charles University Centerfor Ec onomic Research and Graduate Education Academy of Sciences of the Czech Republic Ec onomic s Institute 


\section{Working Paper Series $\quad 369$ (ISSN 1211-3298)}

\section{Stackelberg Leadership with Product Differentiation and Endogenous Entry: Some Comparative Static and Limiting Results}

Krešimir Žigić

CERGE-EI

Prague, October 2008 
ISBN 978-80-7343-169-3 (Univerzita Karlova. Centrum pro ekonomický výzkum a doktorské studium)

ISBN 978-80-7344-158-6 (Národohospodářský ústav AV ČR, v.v.i.) 


\title{
Stackelberg Leadership with Product Differentiation and Endogenous Entry: Some Comparative Static and Limiting Results
}

\author{
Krešimir Žigić \\ CERGE-EI*, Prague and INTERTIC** Milan
}

\begin{abstract}
Allowing for endogenous entry in the traditional Stackelberg setup with product differentiation, leads to reverting of the standard comparative static and limiting results. Unlike in the standard Stackelberg setup with barriers to entry, the leader's profit increases when the differentiation becomes lower. The reason is that competition becomes tougher when products become more alike, and consequently, fewer firms enter in equilibrium. On the other hand, increasing product differentiation towards its limit results in number of entrants tending to infinity and for very large market, the profit of the leader approaches zero. Thus market structure approaches monopolistic competition, rather than the standard monopoly outcome that occurs with exogenous number of followers.
\end{abstract}

\begin{abstract}
Abstrakt
Dovolíme-li $\quad \mathrm{v}$ tradičním Stackelbergerově uspořádání $\mathrm{s}$ produktovou diferenciací endogenní vstup, získáme opačné výsledky než v tradičním uspořádání. Na rozdíl od tradičního Stackelbergerovského uspořádání se zisk vůdce na trhu zvětšuje s klesající diferenciací. Důvodem je tvrdší konkurence vzešlá z pravděpodobnějšího výskytu produkti̊, což znamená méně firem vstupujících na trh. Na druhou stranu stoupající diferenciace produktů směrem $\mathrm{k}$ jejich možnostem vyúst'uje $\mathrm{v}$ nekonečný počet vstupujících subjektů na trh. Pro velké trhy pak zisk vůdce postupně vymizí. Tedy struktura trhu se spíše blíží $\mathrm{k}$ monopolistické konkurenci než k standartnímu monopolistickému výstupu s exogenním počtem následovníků.
\end{abstract}

Keywords: Stackelberg leadership, product differentiation, endogenous entry JEL Classification: L1, D43

Acknowledgment: I am grateful to A.Dixit, A.Shaked, J.Sutton, P. Katuščak, L.Celik,V.Semerak, I.Maci and M.Kunin for valuable comments. The technical assistance of V.Semerak is greatly appreciated.

* CERGE-EI is a joint workplace of the Center for Economic Research and Graduate Education, Charles University, and the Economics Institute of Academy of Sciences of the Czech Republic.

Address: CERGE-EI, P.O. Box 882, Politických vězňu 7, Prague 1, 111 21, Czech Republic

**http://www.intertic.org/ 


\section{Introduction}

In an influential and pioneering paper, Dixit (1979), among other things, showed that the increasing degree of product differentiation in a standard Stackelberg leaderfollower setup leads to the rise in leader's profit. Clearly, the leader softens the competition through product differentiation and, consequently, realizes higher profit. In the limit if the products could become completely separated (due to the product differentiation), the leader achieves monopoly profit. The key assumption for this result to hold is that the number of potential entrants (or followers) is exogenously set. However, allowing for the endogenous entry in the above Stackelberg framework changes dramatically the already standard comparative statistics results and limit values. In this case profit of the leader declines as product differentiation increases so the leader's profit approaches zero rather than monopoly profit. The underlying assumption for this result is that the demand size of the market does not bind when number of entrants increase with the increased degree of product differentiation.

\section{Model}

To illustrate and to provide underlying intuition for the above statements, consider the following three-stage game ${ }^{1}$ : In the first stage, (i) the leader enters ${ }^{2}$ and pays setup cost, $F$, and chooses its output $q_{L}$. In the second stage (ii) the other firms, the followers, decide whether to enter by paying $F$ each. Finally, in the third stage (iii) those who entered decide on their output, $q_{i}$. Apart from a first mover advantage of the leader, the firms are identical. They compete in quantities; their products are imperfect substitutes.

Much like in Dixit (1979), the demands are assumed to arise from the quasi linear utility function of the form:

$$
\mathrm{u}=\mathrm{U}\left(\mathrm{q}_{\mathrm{i}}, \ldots \mathrm{q}_{\mathrm{m}}\right)+\mathrm{q}_{0}
$$

\footnotetext{
${ }^{1}$ See Etro, 2007 and 2008 for a comprehensive review of Stackelberg models with endogenous entry.

${ }^{2}$ We assume that a monopoly always justifies its fixed cost so the first firm would always want to enter. In addition $F<(a-c)^{2} / 16$ for entry to take place.
} 
where $\mathrm{q}_{0}$ serves as numeraire and the subutility function, $\mathrm{U}\left(\mathrm{q}_{\mathrm{i}}, \ldots \mathrm{q}_{\mathrm{n}}\right)$ describes the utility that a consumer derives from the consumptions of differentiated goods and, like in Dixit (1979), we assume it to be concave and quadratic. There is finite number of consumers each having finite income $Y_{j}<\infty$. The resulting inverse demands for differentiated goods facing each firm $i$ are then $P_{i}\left(q_{i}, \sum_{j \neq i} q_{j}\right)=a-q_{i}-b \sum_{j \neq i} q_{j}$, where parameter $b \in$ $(0,1)$ captures the degree of product differentiation or substitutability among the products $^{3}$. Furthermore, all firms must pay fixed setup cost $F>0$ to enter, and they incur variable unit cost $\mathrm{c}>0$ that is constant.

\subsection{A Follower's problem}

By backward induction, we first solve for the followers' optimal choice of output taking the leader's output $q_{L}$ and the number of followers, $m$, that entered the market as given. After that we solve for $m$ as a function of the $q_{L}$ and finally we use this "response" of the number of entrants and each $q_{i}$ as conditions in the leader's problem. Hence, each follower's problem is

$$
\max _{q_{i}}\left\{\pi\left(q_{i}, q_{L}\right)\right\}=\max _{q_{i}}\left\{\left(P_{i}-c\right) q_{i}-F\right\}
$$

Taking the first order conditions and solving for the symmetric equilibrium among followers we obtain:

$q_{i}\left(q_{L}, m\right)=\frac{\left(a-c-b \cdot q_{L}\right)}{2+b(m-1)}$

We now find the profit of each follower and solve for the number of followers as a function of the leader's strategy, $m\left(q_{L}\right)$ by using the zero profit condition:

$$
m\left(q_{L}\right)=\frac{a-c-(2-b) \sqrt{F}-b \cdot q_{L}}{b \sqrt{F}}
$$

\footnotetext{
${ }^{3} \mathrm{We}$ assume that $\mathrm{b}$ is small enough so that the accommodation of entry is the optimal strategy of the leader. As is well known, when the products get less differentiated the entry deterrence eventually becomes an optimal strategy.
} 
Not surprisingly, the number of followers falls with $q_{L}$. The more aggressively the leader behaves the fewer places there are in the market for followers.

It is interesting however, to see how the output of each follower changes in equilibrium with the leader's output, since there are two opposite effects at work. The first is the direct response effect $\partial q_{i}\left(m, q_{L}\right) / \partial q_{L}$ that is clearly negative as seen from (1). The second indirect effect stems from the fact that an increase in leader's output reduces the numbers of followers in equilibrium (see (2)) and thus has positive effect on follower's output since $\left(\partial q_{i}\left(m, q_{L}\right) / \partial m\right)\left(d m / d q_{L}\right)>0$. It turns out that the two above described effects exactly offset each other so the follower's action does not change with the leader's strategy.

To see this, we plug (1) into (2) to obtain the net response in the follower strategy: $q_{i}^{*}\left(q_{L}\right)=\sqrt{F}$. The ensuing price that a typical follower charges is $p_{i}=c+\sqrt{F}$. The finding that equilibrium strategy of a follower is not affected by the leader's strategy when entry is free holds for a rather general setup and for a large variety of market conducts (see Etro, 2004, 2007 and 2008). Hence, $q_{L}$ will only affect the total output of the followers through $m$, not through $q_{i}$.

\subsection{The leader's problem}

Finally, the leader's problem is

$$
\max _{q_{L}}\left\{\pi_{L}\right\}=\max _{q_{L}}\left\{\left(a-c-m \cdot b \cdot q-q_{L}\right) q_{L}-F\right\}
$$

Taking first order conditions and substituting (1) and (2) in it, we obtain

$q_{L}=\frac{(2-b) \sqrt{F}}{2(1-b)}>q_{i}$

and the corresponding price: $p_{L}=c+\frac{1}{2}(2-b) \sqrt{F}<p_{i}$.

Thus the leader produces more than each follower and charges lower price than each follower. The leader's equilibrium profit is now: 
$\pi_{L}=\frac{b^{2} F}{4-4 b} \cdot{ }^{4}$

We also solve for the equilibrium number of followers $m$ by plugging (3) into (2) to obtain:

$m^{*}=\frac{a-c}{b \sqrt{F}}+1-\frac{2-b}{2(1-b)}-\frac{2}{b}$

\subsection{Comparative static and limiting results}

As immediately seen from (4) the leader's accommodation profit in our setup is increasing in differentiation parameter $b$. The intuition is that, when products get more alike, competition becomes tougher, and, as a consequence, fewer firms enter in equilibrium $^{5}$. In other words, the leader can afford to squeeze out of the market more potential entrants as products become less differentiated. ${ }^{6}$ Consequently, increasing product differentiation (letting $b$ move towards zero) leads again to the "non-standard" but intuitive result. In this case, the number of firms entering the market would tend to infinity (see Appendix 1) and the profit of the leader would go towards zero.

\footnotetext{
${ }^{4}$ Note that the leader's profit does not depend on either $a$ or $c$ which are assumed to be the same for both the leader and the followers. Let us now introduce the notion of the net absolute advantage (see Dixit 1979) that is defined as $\theta_{j}=a_{j}-c_{j}$ where $j=i, L$ and that reflects another aspect of product differentiation. Also allow for different values of these parameters, that is $\theta_{L} \neq \theta_{i}$. In this case the leader's profit equals

$\pi_{L}=\frac{b^{2} F}{4-4 b}+\frac{\left(\theta_{L}-\theta_{i}\right)\left(2(2-b) \sqrt{F+}\left(\theta_{L}-\theta_{i}\right)\right)}{4(1-b)}$.

Thus, the leader's profit comprises in general of two parts: the one that stems from the difference in the net absolute advantage (note that this term also increases in $b$ but apparently vanishes if there is no net absolute advantage) and the other part that represents the pure leadership profit originating from the first mover's advantage.

${ }^{5}$ This is a rather general phenomenon and could be also observed in different setups with free entry. For instance, in a corresponding setup with price competition and Dixit-Stiglitz demand, or logit demand, the equilibrium number of firms is also falling as products gets less differentiated (see also Sutton, 1991 for the notion of toughness of price competition).

${ }^{6}$ By the same token, and again completely opposite from the case with exogenous number of followers, leader's accommodation profit increases in setup costs parameter $F$, since it also leads to lower number of entrants in equilibrium.
} 
Alternatively, we can see that, as expected, increased degree of product differentiation enables leader to charge higher price and to produce less in equilibrium. As a consequence, the leader's price tends to the price of a typical follower and the leader's output goes to the output of a typical follower as the degree of product differentiation tends towards its limit.

Thus,

$$
\lim _{b \rightarrow 0}\left\{c+\frac{1}{2}(2-b) \sqrt{F}\right\}=\lim _{b \rightarrow 0}\left\{a-b \cdot m^{*} \cdot q^{*}-q_{L}\right\}=c+\sqrt{F}
$$

and

$$
\lim _{b \rightarrow 0}\left\{\frac{(2-b) \sqrt{F}}{2(1-b)}\right\}=\sqrt{F}
$$

yielding $\lim _{b \rightarrow 0}\left\{\pi_{L}\right\}=0$.

However, some caveats are in order here. First, recall that in our specification parameter $b$ cannot assume value zero since $b=0$ would imply entry of infinitely many firms and consumers would consume infinitely many varieties. Given the finite size of the market (finite consumer income and fine number of consumers) this is not possible. Second, even if $b$ never attains value of zero, one has still to be careful here since increasing the degree of product differentiation (that is, moving $b$ towards zero) results, as we saw, in increasing number of firms. This in turn, leads to increased supply that would likely bump at the demand constraint at some point (provided that this constraint was not violated at already initial point). ${ }^{7}$ Thus, if we wish to push $b$ "quite close" to zero and not face the above constraint, a consumer's income has to be rather "large".

\footnotetext{
${ }^{7}$ Note that the similar models coming from the new theory of market leaders (see Etro, 2007 and 2008) do not explicitly have the demand constraint but implicitly assume that market size (or income) is always large enough not to be binding.
} 
More specifically, we have to make sure that the income is large enough so that demand for the numeraire is always non-negative ${ }^{8}$ (see Appendix 2).

To summarize, we can say that as b moves towards zero and the markets in question are "very large" markets, the leader's profit approaches arbitrarily close to zero (but actually never reaches it) and so the industry structure approaches a long-run monopolistic competition. This is arguably a strikingly different outcome than the one with exogenous number of followers whereby increased product differentiation results in leader's monopoly position in the limit (see Fig 1 and Dixit, 1979 for the latter).

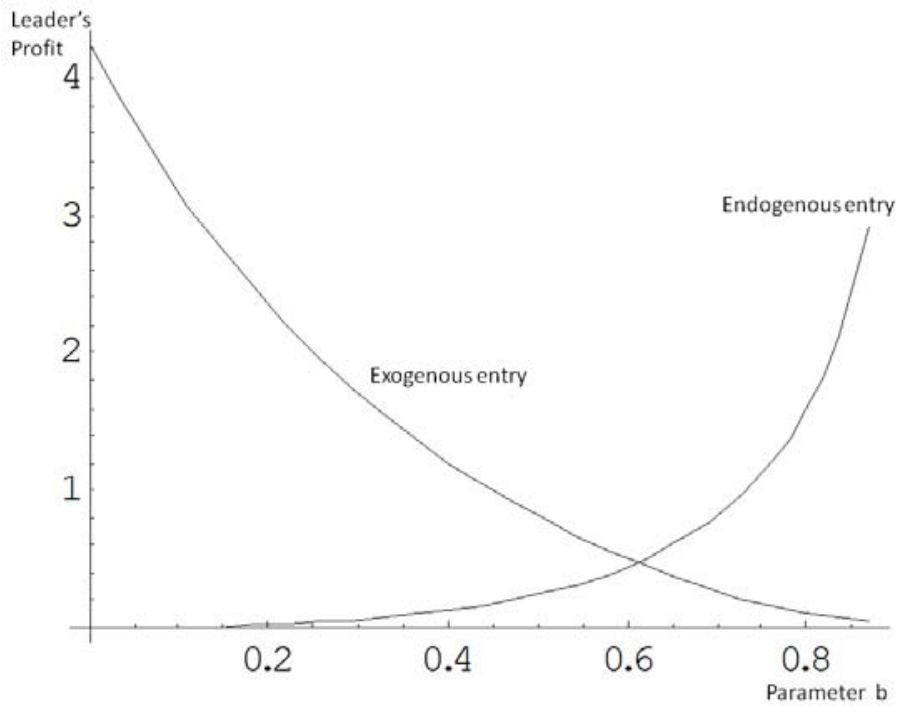

Figure 1

\section{Conclusion}

We demonstrate that the presence of endogenous entry in the standard Stackelberg setup with product differentiation leads to reverting of the standard comparative static and limiting results. Unlike in the standard Stackelberg setup with

\footnotetext{
${ }^{8}$ Alternatively, when consumers' income is insufficient to absorb even the supply of differentiated goods, there will be rationing of the entrants so the demand constraint rather than "free entry" will be determining the number of firms in the market. More specifically, in our case $\mathrm{m} *(\mathrm{Y})$ will be determined from the equality

$\mathrm{Y}=\mathrm{m} \mathrm{p}_{\mathrm{i}}\left(\mathrm{q}_{\mathrm{i}}, \mathrm{q}_{\mathrm{L}}\right) \mathrm{q}_{\mathrm{i}}+\mathrm{p}_{\mathrm{L}}\left(\mathrm{q}_{\mathrm{i}}, \mathrm{q}_{\mathrm{L}}\right) \mathrm{q}_{\mathrm{L}}$ rather than from $\mathrm{m}^{*}(\mathrm{~b})$ whereby $\mathrm{m}^{*}(\mathrm{Y})<\mathrm{m}(\mathrm{b})$ for "small" consumers' income.
} 
barriers to entry (that is, with the number of followers exogenously given), the leader's accommodation profit in our setup increases in differentiation parameter $b$. The reason is that competition becomes tougher when products get more alike, and consequently, fewer firms enter in equilibrium. More interestingly, pushing product differentiation to its limit has as a consequence that the number of firms that enter the market increases and, for the arbitrary large market the profit of the leader tends (arbitrarily close) to zero. Thus the resulting market structure is approaching to monopolistic competition rather than the standard monopoly outcome that occurs with exogenous number of followers. 


\section{References:}

Dixit, A. (1979). A model of duopoly suggesting a theory of entry barriers. Bell Journal of Economics, 10 (1), 20-32.

Etro, F. (2004). Innovation by Leaders, The Economic Journal, Vol. 114, 495 (April), pp. 281-310.

Etro, F. (2007). Competition, innovation and antitrust: A theory of market leaders and its policy implications. Berlin \& New York: Springer Verlag.

Etro, F. (2008). Stackelberg Competition with Endogenous Entry, The Economic Journal, forthcoming

Sutton, J. (1991). Sunk cost and market structure. Massachusetts: MIT Press. 


\section{Appendix 1}

First, it is straightforward to see that

$\lim _{b \rightarrow 0}\left\{m^{*}\right\}=\lim _{b \rightarrow 0}\left\{1-\frac{2-b}{2(1-b)}-\frac{2}{b}+\frac{a-c}{b \sqrt{F}}\right\}=\infty$

Next, we show that $d m * / d b<0$ for all value of $b \in(0,1)$. Treating $m$ for simplicity as a real number, the derivative of $m^{*}$ with respect to $b$ is written as:

$\frac{d m^{*}}{d b}=\frac{1}{2 b^{2}}\left[\frac{(2-b)(2-3 b)}{(1-b)^{2}}-\frac{2(a-c)}{\sqrt{F}}\right]$

so that

$\operatorname{Sign}\left[\frac{d m^{*}}{d b}\right]=\operatorname{Sign}\left[\frac{(2-b)(2-3 b)}{(1-b)^{2}}-\frac{2(a-c)}{\sqrt{F}}\right]$.

We now label the above term in the brackets as $B=\frac{(2-b)(2-3 b)}{(1-b)^{2}}-\frac{2(a-c)}{\sqrt{F}}$.

Note that $\mathrm{B}$ reaches its maximal value at the limit value of $b=0$ since the first part of $\mathrm{B}$ is clearly positive and increases as b tends to zero while the second part of B does not depend on $b$. To see this, we label the first part of $\mathrm{B}$ as $\mathrm{B}_{1}$, so

$B_{1}=\frac{(2-b)(2-3 b)}{(1-b)^{2}}$

and

$\frac{d B_{1}}{d b}=\frac{2 b}{(-1+b)^{3}}<0$

Taking the limit of $\mathrm{B}$ when $b$ tends to zero, we obtain

$\lim _{b \rightarrow 0}\{B\}=4-\frac{2(a-c)}{\sqrt{F}}$. 
Despite the fact that (A1) is the highest value of $\mathrm{B}$, it has still to be negative given our assumption. Namely negativity of (A1) would imply that

$$
F<\frac{(a-c)^{2}}{4} \text {. }
$$

However, from footnote 2 , we recall that

$$
F<\frac{(a-c)^{2}}{16}
$$

for an equilibrium with entry to be viable. Thus $B(b=0)$ has to be negative implying that both $B<0$ and, consequently $d m * / d b<0$.

Alternatively, negativity of (A1) also implies that $\sqrt{F}<(a-c) / 2$, that is, the optimal output of a monopolist has to be bigger than the output of a follower in a free entry equilibrium.

\section{Appendix 2}

As well know, the demand for numeraire good, $\mathrm{q}_{0}$ is given by

$q_{0}\left(p_{i}, p_{L}, Y\right)=Y-\sum_{i^{\prime}=1}^{m}\left[p_{i} q_{i}\left(p_{i}, p_{L}\right)-q_{L} p_{L}\right]$

Now we invert inverse demands $p_{i}$ and $p_{L}$ to obtain direct demands, $q_{i}$ and $q_{L}$ that is written as:

$q_{i}\left(p_{i}, p_{L}\right)=\frac{a(1-b)-p_{i}+b \cdot p_{L}}{(1-b) \cdot(1+b \cdot m)}$

and

$q_{L}\left(p_{i}, p_{L}\right)=\frac{a(1-b)-p_{L}+b \cdot\left(m \cdot p_{i}+p_{L}-m \cdot p_{L}\right)}{(1-b) \cdot(1+b \cdot m)}$

Substituting (2A 2) together with the equilibrium prices $p_{i}=c+\sqrt{F}$ and

$$
\begin{aligned}
& p_{L}=c+\frac{1}{2}(2-b) \sqrt{F} \text { into (2A 1) we obtain: } \\
& q_{0}(b, m(b))=F \cdot m \cdot\left(\frac{1}{1+b \cdot m}+\frac{b^{3}}{4(1-b)(1+b m)}\right)+
\end{aligned}
$$




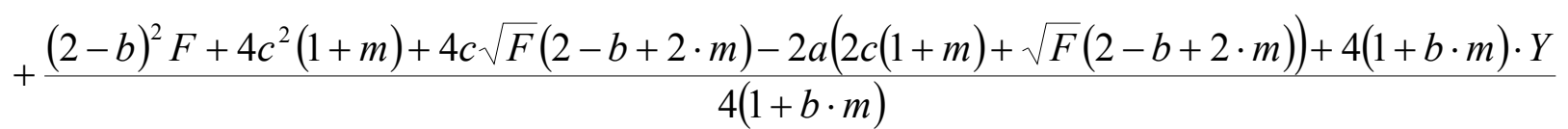
$(2 \mathrm{~A} 3)$

Finally, substituting m(b) into (2A 3) where

$m^{*}=\frac{a-c}{b \sqrt{F}}+1-\frac{2-b}{2(1-b)}-\frac{2}{b}$

we get:

$q_{0}(b)=\frac{(2-b)^{3} F+4(1-b)\left[c^{2}-a(c+\sqrt{F})+(3-b) c \sqrt{F}+b Y\right]}{4(1-b) b}$

To obtain a minimal level of income, $Y$, that for the given differentiation parameter $b$ would not violate the demand constraint for numeraire, we set (2A 4) to zero and solve for Y (see Fig 2A)

$Y=\frac{4(1-b)(a-c) c+4(1-b)[a-(3-b) c] \sqrt{F}-(2-b)^{3} F}{4(1-b) b}$

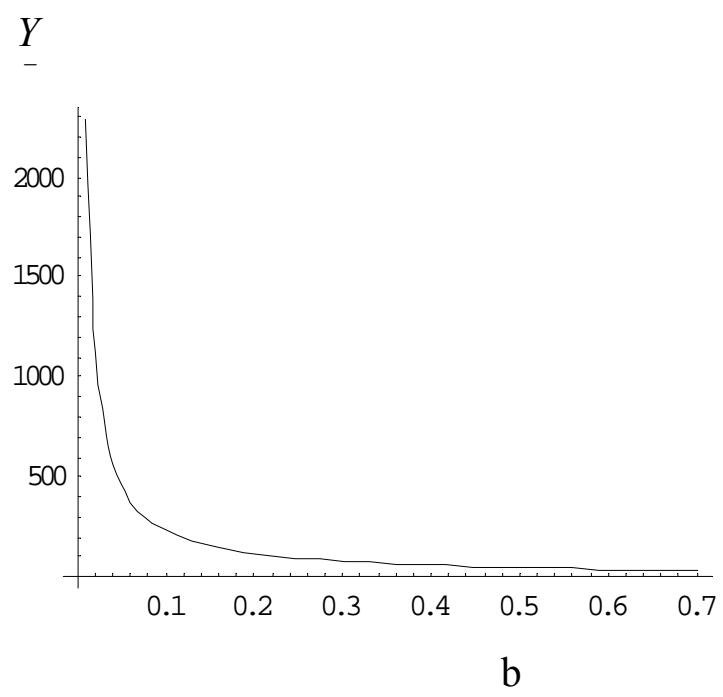


Individual researchers, as well as the on-line and printed versions of the CERGE-EI Working Papers (including their dissemination) were supported from the following institutional grants:

- Economic Aspects of EU and EMU Entry [Ekonomické aspekty vstupu do Evropské unie a Evropské měnové unie], No. AVOZ70850503, (2005-2010);

- Economic Impact of European Integration on the Czech Republic [Ekonomické dopady evropské integrace na ČR], No. MSM0021620846, (2005-2011);

Specific research support and/or other grants the researchers/publications benefited from are acknowledged at the beginning of the Paper.

(c) Krešimir Žigić, 2008.

All rights reserved. No part of this publication may be reproduced, stored in a retrieval system or transmitted in any form or by any means, electronic, mechanical or photocopying, recording, or otherwise without the prior permission of the publisher.

Published by

Charles University in Prague, Center for Economic Research and Graduate Education (CERGE) and

Economics Institute ASCR, v. v. i. (EI)

CERGE-El, Politických vězňŭ 7, 11121 Prague 1, tel.: +420 224005 153, Czech Republic.

Printed by CERGE-EI, Prague

Subscription: CERGE-EI homepage: http://www.cerge-ei.cz

Editors: Directors of CERGE and EI

Managing editors: Deputy Directors for Research of CERGE and EI

ISSN 1211-3298

ISBN 978-80-7343-169-3 (Univerzita Karlova. Centrum pro ekonomický výzkum

a doktorské studium)

ISBN 978-80-7344-158-6 (Národohospodářský ústav AV ČR, v. v. i.) 
CERGE-EI

P.O.BOX 882

Politických vězňů 7

11121 Praha 1

Czech Republic http://www.cerge-ei.cz 